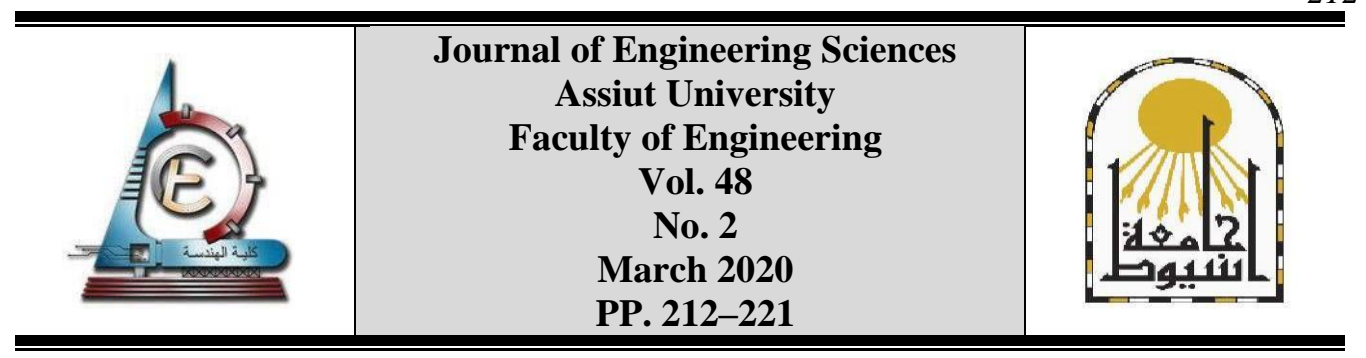

\title{
EFFECTS OF WELDING PARAMETERS ON CHARACTERIZATION AND MECHANICAL PROPERTIES OF STEEL 37 WELDMENTS
}

\author{
Mohamed M. Ali * and Moatasem M. Kh \\ Mining and Petroleum Eng. Dep., Faculty of Engineering, Al-Azhar University, Qena, Egypt
}

Received 26 February 2020; Accepted 3 March 2020

\begin{abstract}
Effects of welding parameters on the characterization and mechanical properties of steel 37 weldments were investigated on a single $\mathrm{V}$-shaped groove weld joint. These parameters are; type of electrode, welding current, welding speed, and type of used arc welding and plate thickness. Radiography, metallography and mechanical testing were carried out for the steel 37 weldments.

Results indicated that as the heat input increased, the welding current and plate thickness increased but the welding speed decreased. The grains of the base metal, heat affected zoon (HAZ), root and cap were changed in size and phases in these locations. Radiography showed that no defects were found. The average hardness values were $173 \mathrm{HB}$ at base metal, $175 \mathrm{HB}$ at the HAZ, $180 \mathrm{HB}$ at the cap and $133 \mathrm{HB}$ at the root, respectively. Yield strength, ultimate tensile strength and elongation of the welded steel 37 were in the range between 374 and $425 \mathrm{MPa}$, between 542 and $606 \mathrm{MPa}$ and in the range between 34.6 and $37.5 \%$, respectively. Such values tend to increase with increasing the current and heat input and decreasing the plate thickness. The chemical and mechanical properties of the welded electrodes proved to influence the efficiency of the welding process. The best welding results were obtained with current $75 \mathrm{~A}$ at the root, $130 \mathrm{~A}$ at the cap and welding speed of $1.3 \mathrm{~mm} / \mathrm{s}$ in the root and $2 \mathrm{~mm} / \mathrm{s}$ in the cap.
\end{abstract}

Keywords: Steel 37 - Weldments- Welding variables- Hardness -Tensile strength- Elongation.

\section{Introduction}

Welding process is used to join hundreds of various commercial alloys in many various shapes by heat or pressure or both. Many welded products could even be made, e.g., nuclear power plants, jet aircraft, pressure vessels, ships, boilers, pipelines...etc. [1-3]. Many problems associated with the welding process can be avoided by properly considering properties and process requirements. Identifying the specific process needs to understand a large number of options available, a variety of possible joint configurations, and the many variables that must be defined for each process [4]. Welding processes can be divided into two major kinds, fusion welding- the widely used method in this process is arc welding- and pressure welding. There are different types of arc welding: flux-cored arc

\footnotetext{
* Corresponding author.
}

Email address: mmam64@yahoo.com 
welding (FCAW), gas metal arc welding (GMAW), gas tungsten arc welding (GTAW), plasma arc welding (PAW), shielded metal arc welding (SMAW) and submerged arc welding (SAW) [5]. The type of arc welding depends mostly on the material to be welded.

SMAW process -also known as manual metal arc welding- is used to examine optimum welding current (WI) which is the most important parameter in the arc welding process. WI controls the electrode burn-off rate, the depth of fusion and geometry of the weldment [1, 4].

While increasing the welding speed (Ws) and maintaining constant welding voltage $\left(\mathrm{W}_{\mathrm{V}}\right)$ and WI will reduce the width of the bead and also increase penetration until an optimum speed is reached at which penetration will be maximum. Increasing the speed beyond this optimum will result in decreasing penetration [5, 6]. If the Ws decrease beyond a certain point, the penetration also will decrease due to the pressure of the large amount of weld pool beneath the electrode, which will cushion the arc penetration force [7].

So using the control system in arc welding can remove many of the guess work that workers often use to determine welding factors for a particular task [4]. Heat input (HI) of the welding played an important role in the microstructure of the joints. However, more attention should be given to the effect of HI of the welding on the properties of the area heat affected zone (HAZ), as the weakest area, rather than the base metal (BM) welding [3, 8, and 9].

The main objective of this work was to investigate the effects of welding parameters on the characterization and mechanical properties of steel 37 in single V shaped groove weldments.

\section{Experimental work}

\subsection{Materials}

Steel 37 and many kinds of electrodes were applied during the welding process. The chemical analysis and mechanical properties of steel 37 (base metal) are listed in Table 1 $[3,10]$. This kind of steel 37 based on carbon percentage means that is suitable for producing bars, plates and structural shapes.

Table 1.

Chemical analysis and mechanical properties of steel 37

\begin{tabular}{|c|c|c|c|}
\hline \multicolumn{2}{|c|}{ Chemical analysis } & \multicolumn{2}{c|}{ Mechanical properties } \\
\hline Carbon, \% & 0.2 & Yield strength, MPa & 235 \\
\hline Silicon, \% & 0.15 & Ultimate tensile strength, MPa & 360 \\
\hline Manganese, \% & 0.56 & Brinell hardness, BH & 110 \\
\hline Phosphorus, \% & 0.05 & Elongation at break, \% & 25 \\
\hline
\end{tabular}

For the welding process, the applied electrodes in this work are E6010, E7018 and E70S-3. The chemical analysis and mechanical properties for these electrodes are shown in Tables 2, 3.E6010 electrode has deeper penetration, so it used in root welding, while E7018 electrode has shallower penetration, so it used in weld metal and cap.

Table 2.

Typical chemical analysis for various electrodes

\begin{tabular}{|c|c|c|c|c|}
\hline Elements, $\%$ & Carbon & Silicon & Manganese & Molybdenum \\
electrode and its used & $0.1-0.12$ & $0.14-0.3$ & $0.5-0.51$ & - \\
\hline E6010, (root weld) & 0.08 & 0.35 & 0.8 & 0.45 \\
\hline $\begin{array}{c}\text { E7018(weld metal and cap) in } \\
\text { SMAW weld process }\end{array}$ & $0.006-0.15$ & $0.45-0.75$ & $0.9-0.4$ & $\mathrm{P}=0.025, \mathrm{Cu}=0.5$ \\
\hline E 70S-3, (GMAW weld process)
\end{tabular}


JES, Assiut University, Faculty of Engineering, Vol. 48, No. 2, March 2020, pp. 212-221

Table 3.

Typical mechanical properties for the used electrodes

\begin{tabular}{|c|c|c|c|}
\hline Pind of electrode & $\begin{array}{c}\text { Yield strength } \\
, \mathrm{MPa}\end{array}$ & $\begin{array}{c}\text { Ultimate tensile } \\
\text { strength, MPa }\end{array}$ & $\begin{array}{c}\text { Elongation } \\
\text { at break, \% }\end{array}$ \\
\hline E6010 & $\geq 390$ & $470-540$ & - \\
\hline E7018 & $\geq 480$ & $\geq 560$ & 26 \\
\hline E 70S-3 & $\geq 483$ & 400 & 22 \\
\hline
\end{tabular}

\subsection{Experimental procedures}

Many plates with dimensions $150 \times 100 \times 10 \mathrm{~mm}$ of steel 37 were prepared to weld with a single $\mathrm{V}$ groove butt joint as shown in Figure 1. Two welding technologies (SMAW and GTAW) were used. Joints were made according to the procedural stipulations indicated in applicable code, and may consists of multiple passes as specified on welding procedure specification (WPS) [11]. Manual welding can be carried out using either direct current (DC) or alternating current (AC). With DC WI either positive or negative polarity can be used, so the WI is flowing in one direction. AC WI flows from negative to positive, and in two directional. Power sources for manual welding are either transformer (which transforms the main AC to AC that suitable for welding). In this work, the Miller 9040255, Dig Blue 600 DX apparatus was used.

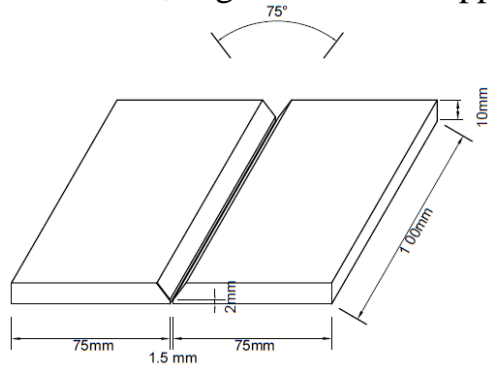

Fig. 1. Sketch of weld edge preparation

\subsection{Preparation of the samples for inspection and testing}

Weldments were prepared after finishing the welding process to make macro and micro examination. Suitable specimens were prepared with dimensions of $30 \mathrm{~mm}$ diameter and $20 \mathrm{~mm}$ thickness. Acidic solution $\left(3 \% \mathrm{HNO}_{3}+97 \%\right.$ Alcohol $\left(\mathrm{C}_{2} \mathrm{H}_{5} \mathrm{OH}\right)$ was prepared to appear the microstructure. The microstructure examinations were carried out by polarized reflected light microscope (Model-OLYMPUS BX51, Japan) supplied with a digital camera (Leica DM500) and four objective lenses of various magnifications. The radiographic test was performed using Iridium 192 to investigate the presence of any internal defects, such as lack of penetration.

The X-rays inspection was used to photo the species \& revealed the surface and subsurface defects and this work was carried out by the X-Ray equipment. X-rays used in the industrial radiography of welds generally have photon energies in the range $30 \mathrm{kV}$ up to 20 MV. The produced weldments were subjected to a series of tests to evaluate some of the mechanical properties such as Brinell hardness $(\mathrm{BH})$ and tensile strength. The $\mathrm{BH}$ has been done by using HB test and the specimens for this test were polished [12].Tensile strength test was performed to characterize weld strength by determining Yield strength (YS) and Ultimate tensile strength (UTS) using a universal testing machine on (VH-F1000 kN) SHIMADZU micro-computer controlled electronic, made in Japan, with strain rate $5 \times 10-3$ $\mathrm{s}^{-1}$ and the specimens were prepared according to ASTM standard test method (the standard width is $10 \mathrm{~mm}$ and the gage length is $60 \mathrm{~mm}$ ) [12]. 


\section{Results and discussion}

\subsection{The parameters affecting the welding process}

Several sets of welding variables were studied for a specific characterization or as a result of the obtained experimental values. These variables include $\mathrm{WI}, \mathrm{W}_{\mathrm{V}}, \mathrm{Ws}$, electrode kind, $\mathrm{HI}$ and plate thickness $(\mathrm{Pt})$ were studied in this work.

The values of these variables were selected within their respective ranges to maintain variability of the variable values and to explore a large range of the welding variables to cover all possible situations as shown below:-

- $\mathrm{W}_{\mathrm{V}}$ value was taken $24 \mathrm{~V}$ during the welding process. While the WI values were changed from 55 to $85 \mathrm{~A}$ at the root and from 110 to $140 \mathrm{~A}$ at the weld metal and cap.

- Various plates' thicknesses $(6,10,15$ and $20 \mathrm{~mm})$ were used.

-Ws is defined as the rate of travel of the electrode along the seam. Ws were changed from 0.9 to $2 \mathrm{~mm} / \mathrm{s}$ in the root and from 1.3 to $4 \mathrm{~mm} / \mathrm{s}$ in the weld metal and cap.

- HI was calculated according to Eq. (1) $[13,14]$.

$\mathrm{HI}=\frac{\mathrm{VXI}}{\mathrm{Ws}}, \mathrm{J} / \mathrm{mm}$

-Welding time (Wt) was varied during welding of all specimens. Ws was calculated for each welded specimen according to Eq. (2) [14].

$\mathrm{Ws}=\frac{\text { Travel of electrode }}{\mathrm{W}_{t}}, \mathrm{~mm} / \mathrm{s}$

\subsubsection{Effect of welding current}

The effect of WI on the HI is shown in Figure 2. HI increases significantly with an increase of WI in the root, filling and cap. This results agreed with the results said that as the WI increases, weld penetration and $\mathrm{HI}$ increase and verse as WI decreases, weld penetration and HI decrease. WI is the greatest factor affecting the degree of the weld penetration $[9,15]$.

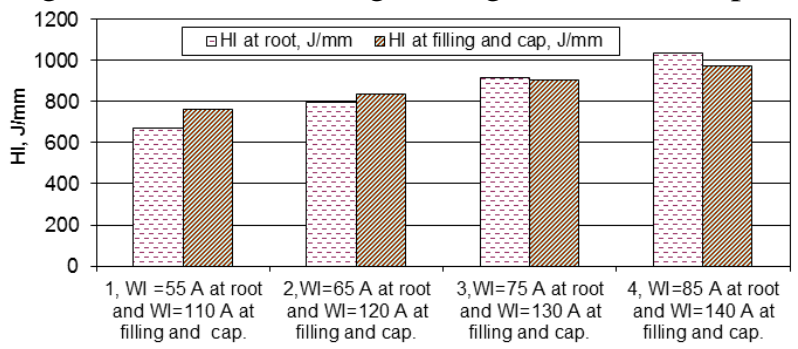

Fig. 2. Effect of welding current on heat input (HI)

\subsubsection{Effect of welding speed}

The relation between Ws and $\mathrm{HI}$ for welded steel at 130 ampere in the cap and filling regions is shown in Figure 3. HI is inversely proportional to the Ws. Therefore, when the Ws decreases the HI increases. This result also achieved in the other studied of WI's in the root, filling and cap regions. So, Ws needs to be adjusted within limits to control the depth of penetration and weld size [13]. 


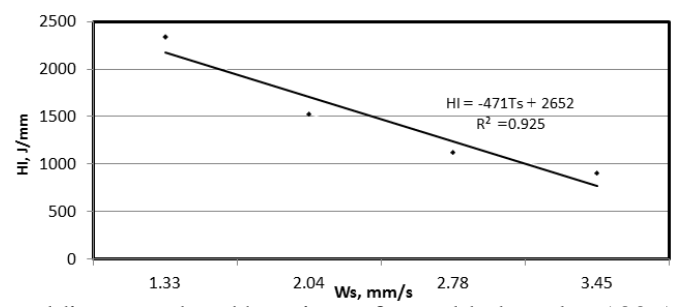

Fig. 3. Relation between welding speed and heat input for welded steel at $130 \mathrm{~A}$ in the cap and filling regions.

\subsubsection{Effect of plate thickness on heat input}

The relation between plates welded using SMAW process at various thicknesses $(6,10,15$ and 20 $\mathrm{mm}$ ) and $\mathrm{HI}$ is shown in Figure 4 at the following conditions (WI=65 A at the root, $\mathrm{WI}=125 \mathrm{~A}$ at the cap, $\mathrm{W}_{\mathrm{V}}=24 \mathrm{~V}$ and $\mathrm{Ws}=2.5 \mathrm{~mm} / \mathrm{s}$ ). The results illustrated that when the Pt increases the HI increases.

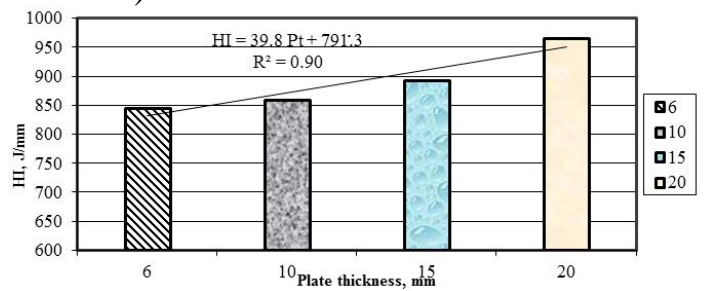

Fig. 4. Effect of HI on plate's thickness at constant WI

\subsubsection{Effects of changing the kind of welding process on heat input}

In this group, kind of process welding was changed from SMAW to GTAW at the same conditions of current and Ws as shown in Table 4 . In this group the Ws at $1.9 \mathrm{~mm} / \mathrm{s}$., $\mathrm{W}_{\mathrm{V}}$ (24 V), and WI 60-65 A in the root and 120-130 Ain the cap. HI increases when GTAW process was used as compared with the SMAW process at constant values of the following parameters WI, $\mathrm{W}_{\mathrm{V}}$ and Ws.

Table 4.

$\mathrm{HI}$ of two processes of welding with at constant WI, Wv and Ws

\begin{tabular}{|c|c|c|c|c|}
\hline Kind of process & Ws, $\mathrm{mm} / \mathrm{s}$ & WI, I & $\mathrm{Pt}, \mathrm{mm}$ & $\mathrm{H}, \mathrm{J} / \mathrm{mm}$ \\
\cline { 1 - 3 } GTAW & \multirow{2}{*}{1.9} & $60-65_{\text {root }}$ & \multirow{2}{*}{10} & 1394 \\
\cline { 1 - 1 } \cline { 1 - 2 } & SMAW & $120-130_{\text {cap }}$ & 10 & 1104 \\
\hline
\end{tabular}

\subsection{Macrostructure examination}

A schematic illustration of bead penetration measurement is shown in Figure 5 and measurement of the width equals $12 \mathrm{~mm}$, size of weld metal equals $11 \mathrm{~mm}$, depth of penetration equals $1.5 \mathrm{~mm}$ and width of root equals $2 \mathrm{~mm}$.

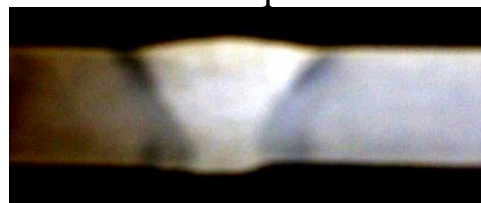

Fig. 5. Macrostructure of the welded metal

\subsection{Microstructure results}

The microstructure of the BM, HAZ, root and cap is shown in Figure 6(A-D). The grains of the BM are coarse pearlite and Alpha ferrite as shown in Figure 6A. Alpha ferrite and pearlite form by the slow cooling of austenite, with the associated rejection of carbon by diffusion. 
Alpha ferrite and pearlite can begin within a temperature range of $900^{\circ} \mathrm{C}$ to $723^{\circ} \mathrm{C}$, and $1150^{\circ} \mathrm{C}$ to $723^{\circ} \mathrm{C}$, depending on the composition of the alloy [8]. Its characteristics by high ductility and low hardness. But, the grains at HAZ are decreased in size as shown in Figure 6B. Because, the HAZ was heated above A1 (lower critical temperature i.e. $723{ }^{\circ} \mathrm{C}$ ) with moderate cooling leads to some of recrystallization causes an internal stress and dislocations. This needs to make partial annealing to remove the dislocation and relief the stresses. Figure $6 \mathrm{C}$ at the root, indicates the metal was melted and moderate cooled so there is a few of internal stress and dislocations. The grains at the cap as shown in Figure 6D are a mixture from martensite and bainite that is originated from the overheating caused by welding operation then fast cooling. The cooling rates of bainite was slower than the martensite formation and faster than the ferrite and pearlite formation [3]. Its characteristics by low ductility and high hardness. So annealing after welding or the welds leave to cool in air was recommended.

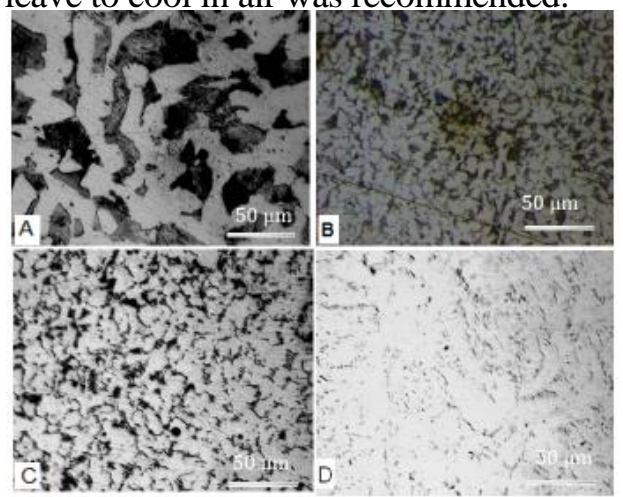

Fig. 6. Microstructure of A) the BM, B) HAZ, C) Root and D) Cap

\subsection{Radiographic results}

The visual appearance of the face, root weld and photos of radiographic films are shown in Figure 7(A-C). It was found that weldment had the best weld quality with no observed defects, and this is due to the applied high HI.

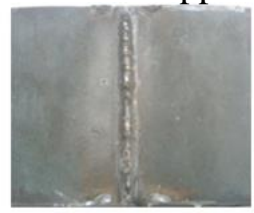

(A) Face

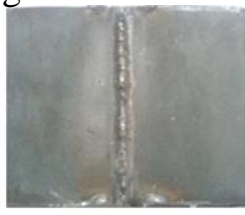

(B) Root

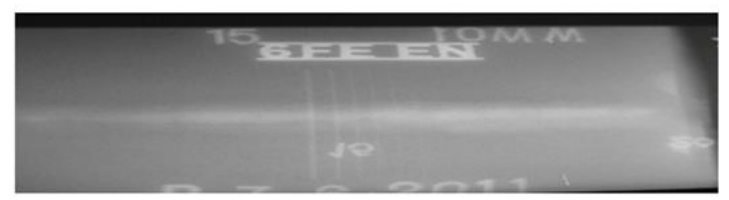

(C) Radiography

Fig. 7. Weld piece at WI $=110 \mathrm{~A}$ at cap, Ws (at face) $=0.9 \mathrm{~mm} / \mathrm{s}$ and $\mathrm{Ws}$ (at root) $=1.3 \mathrm{~mm} / \mathrm{s}$.

\subsection{Mechanical Properties}

\subsubsection{Brinell hardness}

In order to additionally analyze and confirm weld characteristic changes due to the welding process with various parameters, $\mathrm{BH}$ measurements were performed on the welded samples. BH results were processed in 19 points as shown in Figure 8. In general, the BH of 
this specimen is in the range of 101 to $198 \mathrm{HB}$. The regions of $\mathrm{BH}$ measurements were divided into five regions include BM, HAZ, thermo-mechanical affected zone (TMAZ), cap and root. At BM the average value of $\mathrm{BH}$ was found $173 \mathrm{HB}$. At $\mathrm{HAZ}$ the average $\mathrm{BH}$ value was $175 \mathrm{HB}$, while the average $\mathrm{BH}$ of the cap and root were 180 and $133 \mathrm{HB}$, respectively. At TMAZ the average value of $\mathrm{BH}$ was found $160 \mathrm{HB}$. The $\mathrm{BH}$ value in the $\mathrm{BM}$ in each side of the specimen was observed to be nearly compatible constant throughout the material, but the results of all sides' show incompatibility throughout the material. The difference in these results may be due to using the manual welding.

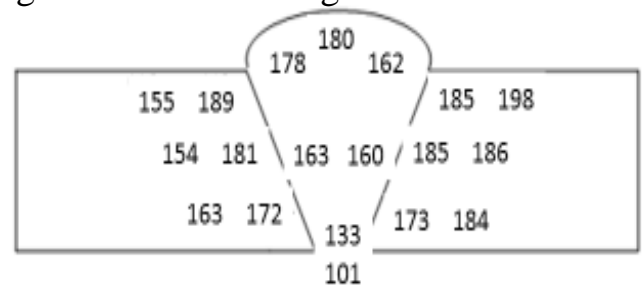

Fig. 8. The BH results on steel welded specimen.

\subsubsection{Tensile strength}

Steel 37 with various plate thicknesses $(6,10$ and $15 \mathrm{~mm})$ were successfully welded at all given welding conditions. The tensile properties for six tested specimens are shown in Table 5and Figure 9. YS of welded steel was ranged between 374 and $425 \mathrm{MPa}$ with an average value of $401 \mathrm{MPa}$. UTS of the welded steel 37 was ranged between 542 and $606 \mathrm{MPa}$ with an average value of $562 \mathrm{MPa}$. El of the welded steel was ranged between 34.6 and $37.5 \%$ with an average value of $35.7 \%$. YS and UTS of the welded steel 37 tend to increase with an increase of WI and HI, and with decreasing the Pt. The UTS has been maximum at WI of 130 ampere in comparison with welded steel 37 at 110 and $120 \mathrm{~A}$. With increasing the WI to $140 \mathrm{~A}$, the UTS still constant and recorded the same value of $130 \mathrm{~A}$ (588 MPa). The maximum value of UTS was obtained when Ws was 1.3 in the root and 2 in the cap $\mathrm{mm} / \mathrm{s}$. Based on the published mechanical data of steel 37 and electrodes [10], it can be observed that the UTS, YS and EL properties of the welded joints are better if compared with properties the base metal(BM). These improved results may be due to the welding was carried out with suitable electrodes (E7018) that has higher mechanical properties than the $\mathrm{BM}$. This result means that the strength of the welded steel 37 is stronger than the BM.

Table 5.

Tensile properties and welding conditions of various steel 37 welded specimens

\begin{tabular}{|c|c|c|c|c|c|c|}
\hline $\begin{array}{r}\text { No. of } \\
\text { specimen }\end{array}$ & Thickness, & \multicolumn{2}{|c|}{ Welding conditions } & $\mathrm{YS}, \mathrm{MPa}$ & UTS, & $\mathrm{EL}, \%$ \\
\hline \multirow{5}{*}{13} & \multirow{5}{*}{10} & $\mathrm{HI}$ in root, $\mathrm{J} / \mathrm{mm}$ & 1016 & \multirow{5}{*}{387} & \multirow{5}{*}{569} & \multirow{5}{*}{34.6} \\
\hline & & HI in filling \&cap & 1320 & & & \\
\hline & & WI, A & 55 in root 110 in cap & & & \\
\hline & & Ws, $\mathrm{mm} / \mathrm{s}$ & 1.3 in the root, 2 in cap & & & \\
\hline & & $\mathrm{Wt}, \mathrm{s}$ & 77 in the root, 55 in cap & & & \\
\hline \multirow{5}{*}{11} & \multirow{5}{*}{10} & $\mathrm{HI}$ in the root $\mathrm{J} / \mathrm{mm}$ & 796 & \multirow{5}{*}{400} & \multirow{5}{*}{542} & \multirow{5}{*}{35.1} \\
\hline & & HI in the filling \&cap & 835 & & & \\
\hline & & WI, A & 65 in the root 120 in cap & & & \\
\hline & & Ws, $\mathrm{mm} / \mathrm{s}$ & $\begin{array}{c}1.96 \text { in the root, } 3.45 \text { in } \\
\text { cap }\end{array}$ & & & \\
\hline & & $\mathrm{Wt}, \mathrm{s}$ & 51 in the root, 29 in cap & & & \\
\hline \multirow{5}{*}{16} & \multirow{5}{*}{10} & $\mathrm{HI}$ in the root, $\mathrm{J} / \mathrm{mm}$ & 1116 & \multirow{5}{*}{421} & \multirow{5}{*}{588} & \multirow{5}{*}{37.5} \\
\hline & & HI in filling \&cap & 1248 & & & \\
\hline & & WI, $\mathrm{A}$ & 75 in the root 130 in cap & & & \\
\hline & & $\mathrm{Ws}, \mathrm{mm} / \mathrm{s}$ & 1.6 in the root, 2.5 in cap & & & \\
\hline & & $\mathrm{Wt}, \mathrm{s}$ & 62 in the root, 40 in cap & & & \\
\hline
\end{tabular}


Table 5. (Cont.)

\begin{tabular}{|c|c|c|c|c|c|c|}
\hline \multirow{5}{*}{3} & \multirow{5}{*}{10} & $\mathrm{HI}$ in the root, $\mathrm{J} / \mathrm{mm}$ & 1571 & \multirow{5}{*}{399} & \multirow{5}{*}{588} & \multirow{5}{*}{35.5} \\
\hline & & $\mathrm{HI}$ in the filling \&cap & 1680 & & & \\
\hline & & \begin{tabular}{|c|} 
WI, A \\
\end{tabular} & 85 in the root 140 in cap & & & \\
\hline & & $\mathrm{Ws}, \mathrm{mm} / \mathrm{s}$ & 1.3 in the root, 2 in cap & & & \\
\hline & & $\mathrm{Wt}, \mathrm{s}$ & 77 in the root, 50 in cap & & & \\
\hline \multirow{5}{*}{17} & \multirow{5}{*}{6} & $\mathrm{HI}$ in the root, $\mathrm{J} / \mathrm{mm}$ & 1108 & \multirow{5}{*}{425} & \multirow{5}{*}{606} & \multirow{5}{*}{35.5} \\
\hline & & HI in filling \& cap & 1152 & & & \\
\hline & & WI, $\mathrm{A}$ & 60 in the root 120 in cap & & & \\
\hline & & $\mathrm{Ws}, \mathrm{mm} / \mathrm{s}$ & 1.3 in the root, 2.5 in cap & & & \\
\hline & & $\mathrm{Wt}, \mathrm{s}$ & 77 in the root, 40 in cap & & & \\
\hline \multirow{5}{*}{19} & \multirow{5}{*}{15} & $\mathrm{HI}$ in the root, $\mathrm{J} / \mathrm{mm}$ & 1386 & \multirow{5}{*}{374} & \multirow{5}{*}{478} & \multirow{5}{*}{35.9} \\
\hline & & $\mathrm{HI}$ in the filling \&cap & 1560 & & & \\
\hline & & WI, A & 75 in the root 130 in cap & & & \\
\hline & & Ws, $\mathrm{mm} / \mathrm{s}$ & 1.3 in the root, 2 in cap & & & \\
\hline & & $\mathrm{Wt}, \mathrm{s}$ & 77 in the root, 50 in cap & & & \\
\hline
\end{tabular}
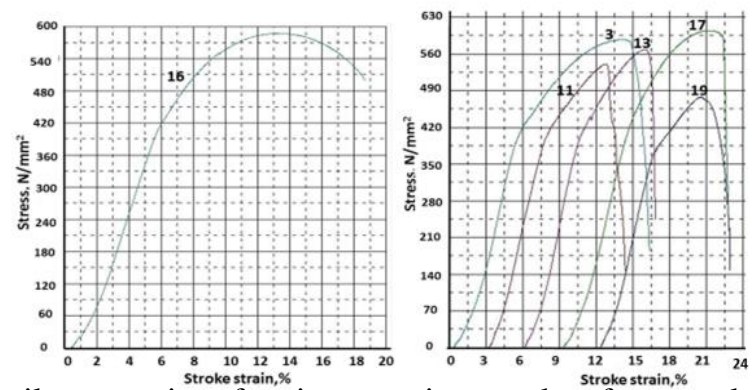

Fig. 9.Tensile properties of various specimens taken from steel 37 weldments.

\section{Conclusions}

- Heat input was proportional inversely with welding speed, and proportional directly with current, plate thickness and efficiency of the welding process (GMAW was greater heat input than SMAW).

- The chemical composition and mechanical properties of the welded electrodes influence the efficiency of the welding process especially the tensile strength properties.

- The hardness of the welded steel 37 was in the range 101 to $198 \mathrm{HB}$. The hardness of the cap was higher than the root. Fine pearlite was formed at the HAZ with high hardness. These results are agreed with the microstructure findings.

- The average yield strength, ultimate tensile strength and elongation of the welded steel 37 were $401,562 \mathrm{MPa}$ and $35.7 \%$, respectively, and tend to increase with increasing the current, and decreasing the plate thickness. UTS have been maximum at welding current of $130 \mathrm{~A}$ as compared with the welded specimens carried out at 110 and $120 \mathrm{~A}$.

\section{Acknowledgements}

The authors would also like to thank A. Nasser M. Omran (Professor of material science, Al-Azhar University- Qena- Egypt), and Dr. Ahmed F. Hassen (The general director of engineering inspection, and the doctor in the field of corrosion in the petroleum companies) for technical assistance and every person helps us during preparing of this work. 
JES, Assiut University, Faculty of Engineering, Vol. 48, No. 2, March 2020, pp. 212-221

Nomenclature

\begin{tabular}{|ll|ll|}
\hline \multicolumn{2}{|c|}{ Nomenclature } & \multicolumn{2}{c|}{ Nomenclature } \\
\hline A & Current, Ampere & MV & Mega volt \\
\hline A1 & Lower critical temperature & PAW & Plasma arc welding \\
\hline AC & Alternative current & Pt & Plate thickness, mm \\
\hline ASTM & $\begin{array}{l}\text { American society for testing } \\
\text { and materials }\end{array}$ & SAW & Submerged arc welding \\
\hline BH & Brinell hardness & SM & Shielded metal \\
\hline BM & Base metal & SMAW & Shielded metal arc welding \\
\hline DC & Direct current, Ampere & TMAZ & $\begin{array}{l}\text { Thermo-mechanical affected } \\
\text { zone }\end{array}$ \\
\hline EL & Elongation, $\%$ & UTS & Ultimate tensile strength, MPa \\
\hline FCAW & Flux-cored arc welding & V & Volt \\
\hline GT & Gas tungsten & WPS & Welding procedure specification \\
\hline GTAW & Gas tungsten arc welding & Ws & Welding speed, mm/sec \\
\hline HAZ & Heat affected zone & W & Welding time, s \\
\hline HI & Heat input, J/mm & Wv & Welding voltage, V \\
\hline MPa & Mega Pascale & YS & Yield strength, MPa \\
\hline
\end{tabular}

\section{REFERENCES}

[1] Rohit Jha, A. K. Jha, (2014), "Investigating the effect of welding current on the tensile properties of SMAW welded mild steel joints", International Journal of Engineering Research \& Technology (IJERT), Vol. 3 (issue 4), pp. 1304 - 1307.

[2] Gopal Krushna mohanta and Ajit kumar Senapati, (2018), "The effect of welding parameter on Mild steel by MMAW", IOP Conf. Series: Materials Science and Engineering 410 doi:10.1088/1757-899X/410/1/012015 pp. 1304 - 1307.

[3] Deepak kamra, Amandeep singh and Harpreet singh, (2015), "Microstructure analysis of shielded metal arc welding using different electrode combination", International Journal for Technological Research in Engineering (IJTRE), Vol. 2 (issue 7), pp. 1138 - 1142.

[4] S.P. Tewari, A. Gopta and J. Prakash, (2010), "Effect of welding parameters on weldability of materials", International Journal of Engineering Science and Technology, Vol. 2 (issue 4), pp.512-516.

[5] Ashish Thakur, Hagos Gebrelibanos and Tadesse Gabrey, (2019), "Arc Welding Process Selection through a Quality and Costs", International Journal of Current Engineering and Technology, Vol.9, No.3, pp. 383-394.

[6] P. Kumari, K. Archna and R.S. Parmar, (2011), "Effect of welding parameters on weld bead geometry in MIG welding of low carbon steel", International Journal of Applied Engineering Research, Vol. 6 (issue 2), pp.249-258.

[7] Cynthia L. Jenney Annette O'Brien, (2007), "Welding Handbook", Ninth Edition Vol. 3, Welding process part 2 technology, Miami, America welding society

[8] Zakaria Boumerzoug, Chemseddine Derfouf and Thierry Baudin, (2010)," Effect of Welding on Microstructure and Mechanical Properties of an Industrial Low Carbon Steel", Engineering, Vol 2, pp. 502-506.

[9] Anil Parmar and Aakash Dubey, (2017) "Study of heat affected zone for SMAW process for low carbon steel specimen with controlled parameters", International Journal of Modern Trends in Engineering and Research (IJMTER) Vol. 4(issue 11), pp. 23-28.

[10] https://www.makeitfrom.com/material-properties/ASTM-A283-Grade-A-Carbon-Steel, 2019.

[11] Welding procedure guide- An easy to follow guide covering the preparation of welding procedure data sheets", September 2008 CWB Group - Industry Services.

[12] ASTM E8 / E8M-13, (2013),"Standard test methods for tension testing of metallic materials", ASTM International, West Conshohocken, PA, www.astm.org

[13] A L Dhobale and H K Mishra, (2015), "Review on effect of heat input on tensile strength of butt weld joint using MIG welding" International Journal of Innovations in Engineering Research and Technology (IJIERT), Vol. 2 (issue 9), pp. 1-13.

[14] Mohd. Suhail, Mohd. Faizan Hasan and P. K. Bharti, (2014), "Effect of welding speed, current and voltage on mechanical properties of underwater welded mild steel specimen $(\mathrm{C}$, 
Mn, Si) with insulated electrode E6013", MIT International Journal of Mechanical Engineering, Vol.4(issue 2), pp. 120-124.

[15] H.R. Ghazvinloo, A. Honarbakhsh- Raouf and N. Shadfar, (2010), "Effect of arc voltage, welding current and welding speed on fatigue life, impact energy and bead penetration of AA 6061 joints produced by robotic MIG welding", Indian Journal of Science and Technology. Vol. 3(issue 2), pp. 156-162.

\section{فحص تأثير متغيرات اللحام علي التوصيف والخواص الميكانيكية للصلب 37}

الملخص:

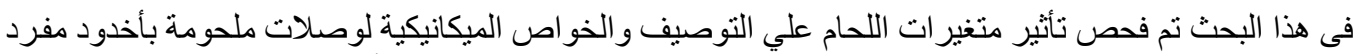

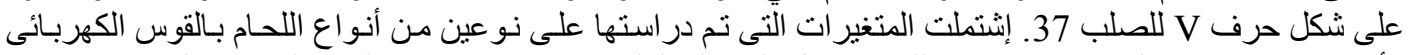

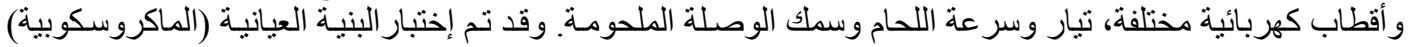
و البنية المجهرية و التصوير الإشعاعي و الصلادة وقوة الثند و الإستطالة للوصلات وصلات الملحومة للصلب 37.

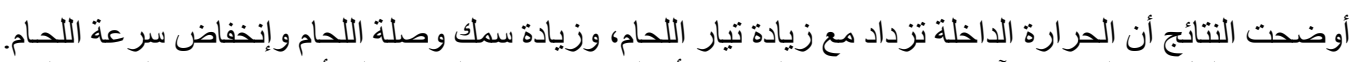

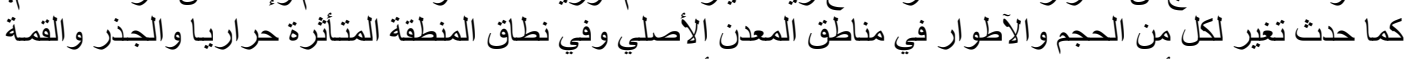

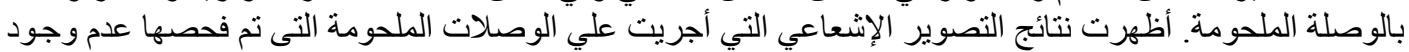

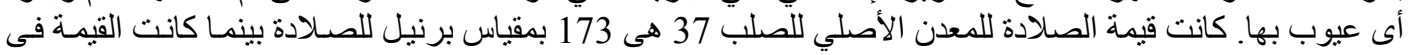

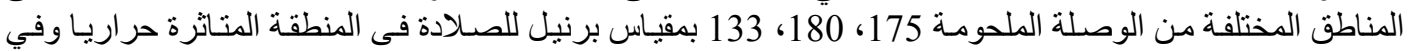

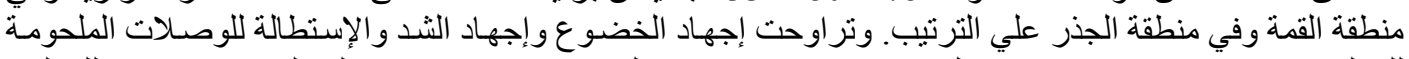

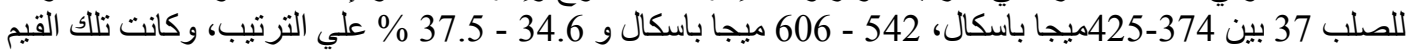
تزداد مع زيادة التيار و الحر ارة الداخلة ونقص سمك الوصلئة المبلة الملحومة. الكلمات الدالة: الصلب 37 - الوصلات الملحومة - متغير ات اللحام- الصلابةــ قوة الثدـ الاستطاله. 